\title{
Knowledge and Attitudes of Students of Faculty of Medicine, YARSI University Towards Hepatitis B Vaccine from the Medical Perspective and Islamic Point of View
}

\author{
Asep Zainuddin Sahir, Ferryal Basbeth \\ Student of General Medicine, Faculty of Medicine, YARSI University, Jakarta \\ Department of Forensic Medicine and Medicolegal, Faculty of Medicine, YARSI University, \\ Jakarta \\ Jalan Letjen Suprapto, Cempaka Putih, Jakarta 10510 \\ Email:ferryal.basbeth@yarsi.ac.id
}

KEYWORDS Knowledge, Attitude, Hepatitis B Vaccine

ABSTRACT Background: Hepatitis B is a major cause of morbidity and death, and is still a health problem for many people in the world. Indonesia is one of the countries that has a medium hepatitis B surface antigen (HBsAg) prevalence, which is between $3.0 \%-18.5 \%$. The main content of a vaccine is a virus or bacteria. In addition to active ingredients, there are adjuvants in the vaccine ingredients. The combination of the main active ingredients (antigens) and adjuvants is more effective than using an antigen vaccine only. In Islam, the vaccination includes preventive treatment measures (wiqayah), therefore the vaccines are subject to legal treatment, with various opinions from halal (permissible) to forbidden. This study aimed to find out the knowledge and attitudes of students of faculty of medicine, YARSI University towards Hepatitis B vaccines viewed from the medical and Islamic perspective. Method: The study used cross sectional research design. The participants of this study were active students of Faculty of Medicine, YARSI University year 2015 by using questionnaire. The total number of students of class 2015 was 250 people. The number of students who met the inclusion criteria was 224 students. Error margin was 5\% with a minimum sample estimate of 144 people. Result: As many as 24\% of the students was aware that hepatitis $B$ vaccine contains aluminum, formaldehyde. Meanwhile, $72 \%$ of the knew that aluminum side effects causes CNS damage. The percentage of students who knew that rejecting the vaccination can be penalized was $27 \%$. While $69 \%$ of the students knew that the provision of vaccine does not require informed consent. About $79 \%$ of the students understood that technique treatment from prophet era as an alternative to increase immunity in children. Regarding the attitudes towards vaccine programs promoted by the government, $31.2 \%$ of the students disagreed. While 33.1\% of the students agreed with the provision of vaccines. The majority of the students (70.8\%) agreed with obtaining informed consent before the vaccination. Moreover, 58\% of the students Were doubtful about education before giving the vaccine. While 58\% of the students disagreed that the technique method can be an alternative to substitute vaccines. Conclusion: Although there was a lack of students' 
knowldge about aluminum content, Thimerosal and formaldehyde in vaccines, the students know that long term use of Hepatitis B Vaccine which contain Aluminum, Thimerosal and Formaldehyde can cause damage to the central nervous system. Regarding the students' attitude towards Hepatitis $B$ immunization, the students agree with the immunization program promoted by the government but they agree that informed consent should be taken and do not know about the sanction if they block or reject the immunization program by the government.

\section{INTRODUCTION}

Immunology develops very quickly, both at the cellular and molecular level, and has succeeded in revealing new things and phenomena through various studies. The progress of this discipline has now been widely applied in the medical field in aspects of prevention, diagnosis and treatment. Understanding the basic principles of immunology is needed to understand immunity related diseases and to apply the latest method that is rapidly developing for the diagnosis and treatment process based on the immunological approach. Medical student at YARSI University learns about vaccines given to the Body Defense Mechanism and Tropical Disease blocks in semester 2 and 3.

The Ministry of Health (Kemenkes) of the Republic of Indonesia changes the concept of complete basic immunization to complete routine immunization. Provision of immunization is adjusted to the age of the child. For complete basic immunization, infants under 24 hours are given Hepatitis B immunization (HB-0), the age of 1 month is given (BCG and Polio 1), the age of 2 months is given (DPT-HB-Hib 1 and Polio 2 ), the age of 3 months is given (DPT-HBHib 2 and Polio 3), the age of 4 months is given (DPT-HB-Hib 3, Polio 4 and IPV or injectable Polio), and the age of 9 months is given (Measles or MR). For advanced immunization, infants under two years (Baduta), the age of 18 months is immunized (DPT-HB-Hib and Measles/MR), grade 1 of elementary/madrasah/equal given (DT and Measles/MR), grade 2 and 5 of elementary school/madrasah/equal given.

Regulation in Indonesia according to the MINISTRY OF HEALTH OF THE REPUBLIC OF INDONESIA NUMBER 12 OF $2017 \quad$ REGARDING MANAGEMENT OF IMMUNIZATION, Article 32 paragraph (3) Arrival of people in Immunization services both indoor and outdoor after being given an explanation as referred to in paragraph (1) and paragraph (2) is an approval for Immunization. Law Number 36 of 2014 Article 69 paragraph 2 Public health services as referred to in paragraph (1) which is Government program does not require approval of action.

Government regulation relating to mandatory immunization in Indonesia is found in Law No. 4 of 1984 regarding Plague, article 5 paragraph (1) letter, namely: "Plague prevention effort includes: prevention and immunization". The only thing that can be done to achieve this goal is immunization. In Article 14 regarding the criminal provision states that,

(1): "Anyone who intentionally obstructs the implementation of plague as 
stipulated in this Law is threatened with imprisonment for a maximum of 1 (one) year and/or a fine of a maximum of IDR $1,000,000$ (one million rupiah)".

(2): "Whosoever due to his negligence results in the obstruction of the implementation of outbreaks as stipulated in this Act, is threatened with a maximum imprisonment of 6 (six) months and/or a maximum fine of IDR 500,000 (five hundred thousand rupiah)".

Vaccines as we understand them in Islam include preventive medical treatment (wiqayah), therefore vaccines are subject to legal treatment, but to date there are two opinions in the world, namely pro-vaccine and anti-vaccine opinions. These differences of opinion are seen from vaccine safety issues, halalness, and conspiracy theories. As a Muslim, studying is a worship as said by the Prophet Muhammad (H.R. Ibn Abdil Barr) thus, it is good to be a state leader, including scientists who are obliged to find out about the effects of good or bad actions for future generations of children.

\section{RESEARCH METHOD}

The design of this study uses a cross sectional research design. The population of this study is students who are registered as active students of Faculty of Medicine, YARSI University year 2015. Inclusion criteria in the form of active students of Faculty of Medicine, YARSI University year 2015, students who have attended IPT and MPT blocks, are willing and signed research informed consent. Exclusion criteria in the form of respondents who have not/have not passed the IPT and MPT blocks, are not willing as respondents, students of Faculty of Medicine, YARSI University outside the year 2015 and students of Faculty of Medicine, YARSI University who have not attended the lecture of IPT and MPT blocks.

\section{RESEARCH RESULT}

\section{Data Characteristics of Respondents}

The results of this analysis are presented in the form of a table taken from the respondents' characteristic data consisting of 154 respondents in the students of Faculty of Medicine, YARSI University year 2015.

Based on table 1 shows that the characteristics of respondents with male 77 are $50 \%$ respondents and women 77 are $50 \%$ respondents. The majority of respondents in the 2015 class are 154 respondents $100 \%$, class of 20140 respondents $0 \%$, year 20160 respondents $0 \%$, and force 20170 respondents $0 \%$. Based on respondents who have followed and passed the IPT block as many as 154 respondents $100 \%$, respondents who have not participated in the IPT block are $0 \%$ $0 \%$, and have not passed the IPT block as much as 0 respondents $0 \%$.

\section{Analysis of Univariate Data Knowledge}

This study aims to determine the level of knowledge and attitudes of students of Faculty of Medicine, YARSI University year 2015 about the Hepatitis $B$ vaccine seen from the point of view of medicine and Islam. Knowledge of the Hepatitis B vaccine is very important to be known by students of Faculty of Medicine, YARSI University year 2015. 
Table 1. Characteristics of Respondents

\begin{tabular}{lcc}
\hline \multicolumn{1}{c}{ Characteristics } & Frequency & Percentage (\%) \\
\hline Sex & 77 & $50 \%$ \\
Male & 77 & $50 \%$ \\
Female & 154 & $100 \%$ \\
Subtotal & & \\
Year & 0 & $0 \%$ \\
2014 & 154 & $100 \%$ \\
2015 & 0 & $0 \%$ \\
2016 & 0 & $0 \%$ \\
2017 & 154 & $100 \%$ \\
Subtotal & & \\
IPT and MPT Blocks Passed & 0 & $0 \%$ \\
Not Following Yet & 154 & $100 \%$ \\
Passed & 0 & $0 \%$ \\
Not Passed/Repeat & 154 & $100 \%$ \\
Subtotal & & \\
\hline
\end{tabular}

Based on table show item questions related to knowledge about the Hepatitis B vaccine. It can be seen that from the five questions posed by researchers the highest assessment of the tofu category is in item number five, namely the question about technique is a preventive action that stimulates immunity in infants. In the question Hepatitis B Vaccine contains Aluminum, Thimerosal and Formaldehyde, knowledge of students who answered did not know as many as 117 students $(76 \%)$, and those who knew only 37 students (24\%). On the question of the long-term side effects of vaccines containing Aluminum and
Thimerosal causing CNS damage, it was found that students who answered knowing Aluminum and Thimerosal side effects caused only 43 student CNS damage (28\%), while 111 students did not know the long-term side effects of Aluminum content and Thimerosal in vaccines or around $72 \%$. In the question about Vaccination, there is no need for informed consent based on applicable regulations in Indonesia, 106 students who answered this or $69 \%$, while 48 students or around $31 \%$ did not know about the need for informed consent on vaccination as a government program. On the question about Physicians who reject vaccines can be convicted, based 
on applicable regulations in Indonesia, the results of 42 students or $27 \%$ who know this while most of the remaining 112 students or $73 \%$ do not know the regulation. On the question about the knowledge that technique is a preventive action that stimulates immunity in infants, it is found that 122 students or $79 \%$ of students know that in Islam there are ways to improve immunization in infants, while 32 students or $21 \%$ of the rest do not know the case.

\begin{abstract}
Attitude
Attitude variables describe the tendency of respondents to make decisions or approve things based on the results of fruit thought. When filling out the questionnaire, it is expected that the respondents can for a moment think about the impact of the Hepatitis B vaccine caused by vaccinating. In this case the researcher wants to know the attitude of the respondents to the use of Hepatitis B vaccine more likely to agree or vice versa. Presented as follows:
\end{abstract}

Table 2. Respondent Frequency Distribution Based on Knowledge Question Item

\begin{tabular}{|c|c|c|c|c|}
\hline Knowledge of Respondents & $\begin{array}{c}\text { Know } \\
\text { (n) }\end{array}$ & Frequency & $\begin{array}{l}\text { Not } \\
\text { Know } \\
\text { (n) }\end{array}$ & Frequency \\
\hline $\begin{array}{l}\text { Hepatitis B vaccine contains } \\
\text { Aluminum, Thimerosal and } \\
\text { Formaldehyde }\end{array}$ & 37 & $24 \%$ & 117 & $76 \%$ \\
\hline $\begin{array}{l}\text { The long-term side effects of the } \\
\text { vaccine contain Aluminum and } \\
\text { Thimerosal causing CNS damage }\end{array}$ & 111 & $72 \%$ & 43 & $28 \%$ \\
\hline $\begin{array}{l}\text { Provision of vaccines does not } \\
\text { require informed consent based on } \\
\text { applicable regulations in Indonesia }\end{array}$ & 106 & $69 \%$ & 48 & $31 \%$ \\
\hline $\begin{array}{l}\text { Doctors who reject vaccines can be } \\
\text { punished, based on applicable } \\
\text { regulations in Indonesia }\end{array}$ & 42 & $27 \%$ & 112 & $73 \%$ \\
\hline $\begin{array}{l}\text { Knowing that technique is a } \\
\text { preventive action that stimulates } \\
\text { immunity in baby }\end{array}$ & 122 & $79 \%$ & 32 & $21 \%$ \\
\hline
\end{tabular}


Table 3. Respondent Frequency Distribution Based on Attitude Question Item

\begin{tabular}{|c|c|c|c|c|c|c|c|c|c|c|}
\hline 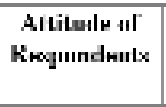 & 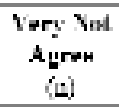 & $\begin{array}{c}\text { Krequinumy } \\
(\mathrm{c})\end{array}$ & $\begin{array}{c}\text { Nol } \\
\text { Agrur } \\
\text { (n) }\end{array}$ & $\begin{array}{c}\text { Fruluenry } \\
\text { (0) }\end{array}$ & $\begin{array}{c}\text { dumbulnil } \\
\text { (n) }\end{array}$ & $\begin{array}{c}\text { Krodgumey } \\
(\mathrm{cos})\end{array}$ & $\begin{array}{l}\text { Ayrum } \\
\text { (n) }\end{array}$ & $\begin{array}{c}\text { Krowaumey } \\
\text { (a) }\end{array}$ & $\begin{array}{l}\text { Vury } \\
\text { Ayrw } \\
\text { (D) }\end{array}$ & $\begin{array}{c}\text { Freilumill: } \\
(\%)\end{array}$ \\
\hline 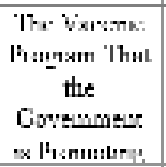 & 16 & 10.4 & $4 \mathrm{x}$ & 31 & 44 & 356 & 34 & 3.1 & 12 & 98 \\
\hline $\begin{array}{l}\text { Aleret ath } \\
\text { Vaccive } \\
\text { Insm! }\end{array}$ & 32 & 20,8 & 32 & 20,8 & 26 & 18,2 & 51 & 13,1 & 11 & 7,1 \\
\hline 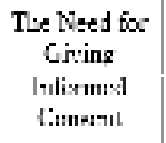 & 6 & 3,9 & 8 & 5,2 & 1 & 2,6 & 27 & $15: 5$ & 109 & 20,8 \\
\hline 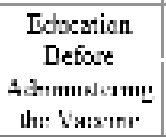 & 5 & 3,2 & 3 & 1,9 & 89 & 87,8 & 50 & 325 & 7 & 1,3 \\
\hline 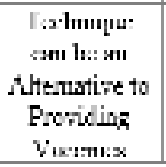 & 4 & 43 & 8: & 28 & ; & 34 & $1:$ & 11 & 5 & Actival. \\
\hline
\end{tabular}

From table 3, it can be seen that student attitudes toward the vaccine program promoted by the government, 44 students answered doubtfully or $31.2 \%$. The attitude of students agree with the provision of vaccines is $33.1 \%$. The attitude of students in giving informed consent before the vaccination was $70.8 \%$ or 109 students chose this attitude. Education before giving the vaccine as many as 89 students chose an attitude of doubt. While the attitude of students that the technique method could be an alternative as a substitute for vaccines, 89 students $(57.8 \%)$ stated they do not agree.

\section{CONCLUSION}

The lack of students' knowledge of Aluminum content, Thimerosal and formaldehyde in vaccines, but students know that long-term side effects of Hepatitis B Vaccine contain Aluminum, Thimerosal and Formaldehyde can cause damage to the central nervous system.
While the attitude of students towards government policies regarding the Hepatitis B vaccine, the attitude of students towards the vaccine program promoted by the government is hesitant, but agrees with vaccinations which require informed consent. Because of the lack of knowledge given at the time of taking the Block of the Science of Tropical Disease (IPT) and the Body Defense Mechanism (MPT), students chose to be hesitant in giving education before giving vaccinations. Students know Vaccine does not require informed consent based on applicable regulations in Indonesia, but students do not know that Doctors who reject vaccines can be punished, based on applicable regulations in Indonesia. Students' knowledge of technique is a preventive action that stimulates immunity in infants is good but the attitude of students that the technique can be an alternative as a substitute for vaccines is disagree. 
KNOWLEDGE AND ATTITUDES OF STUDENTS OF FACULTY OF MEDICINE, YARSI

\section{Research Limitation}

1. In this study using analytical cross sectional design, so that the shortcomings cannot know the cause and effect of the variables studied and the topics studied.

2. The research questionnaire using the SPSS method, does not describe well and broadly how the knowledge and attitudes of the respondents studied.

3. The design of the research used by univariate type researchers has deficiencies only describing extensive and not detailed data results such as in the bivariate or multivariate method.

\section{REFERENCES}

Ahmad, Sarwat. 2016. Benarkah Hukum Imunisasi Mutlak Haram? [on-line]. Rumah Fiqih Indonesia. Cited 2019, June 24. Available from: http: //www.rumahfiqih.com/x.php?id=13 $\underline{69554754}$

Is aluminum in vaccines safe, or toxic? Why is aluminum in vaccines? [online]. Aluminum in Vaccines: History and Toxicity. 2017. Cited 2019, June 23. from: https://thinklovehealthy. com/2017/06/22/aluminum-in-vaccin es-history-and-toxicity/

Kurikulum. Faculty of Medicine [online]. cited 2019, June 24. from: http://fk.YARSI.ac.id/en/kurikulum/

Miller, N. Z,. "Aluminum in Childhood Vaccines Is Unsafe", Journal of American Physicians and Surgeons, 21(4). 109-16.

Offit. P. A. 2019. Vaccine Ingredients Aluminum. Children's Hospital of Philadelphia 2018 [on-line]. Cited, June 24. from: https://www. chop.edu/centersprograms/vaccineed $\underline{\text { ucation-center/vaccineingredients/alu }}$ minum

Palevsky. L. B. 2019 Aluminum and Vaccine Ingredients: What Do We Know? What Don't We Know? [online]. National Vaccine Information Center Your Health. Your Family. Your Choice. Cited, June 23. from: https://www.nvic.org/Doctors-Corne $\mathrm{r} /$ Lawrence-Palevsky/Aluminum-and Vaccine-Ingredients.aspx

PERATURAN MENTERIKESEHATAN REPUBLIK INDONESIA NOMOR 12 TAHUN 2017 TENTANG PENYELENGGARAAN

IMUNISASI. Hukor Kemenkes [online]. cited 2019, June 24. from: http://hukor.kemkes.go.id/uploads/ produk hukum/PMK No. $12 \mathrm{ttg}$ Penyelenggaraan Imunisasi .pdf

Poole, R. L., et.al. "Aluminum Exposure in Neonatal Patients Using the Least Contaminated Parenteral Nutrition Solution Products", Nutrients, 4. 1566-74.

Rencana Strategis Kementrian Kesehatan Tahun 2015-2019. Kementrian Kesehatan Republik Indonesia [online]. cited 2019, June 24. From: http://www.depkes.go.id/resources/ download/info-publik/Renstra 2015.pdf

Rigolet, M., et.al. 2019. Clinical features in patients with long-lasting macrophagicmyofasciitis [on-line]. cited, June 24. from: https://www.frontiersin.org/article/10 3389/fneur.2014.00230

Sharon, Thomas., BREAKING RESEARCH: Hepatitis B vaccine can lead to brain-damaging effects [online]. Natural Health 365. 2018. Cited 2019, June 24. From: https://www.nat uralhealth365.com/hepatitis-b vaccine-dangers-2774.html 
UNDANG-UNDANG NOMOR 4 TAHUN 1984 TENTANG WABAH PENYEKIT MENULAR. Tatanusa [on-line]. Cited 2019, June 24. from: http://www.tatanusa.co.id/nonkuhp 1984UU04.pdf

UNDANG-UNDANG REPUBLIK INDONESIA NOMOR 36 TAHUN 2014 TENTANG TENAGA KESEHATAN. Hukum Online [online]. Cited 2019, June 24. From: https://www.hukumonline.com/pusat data/download/1t5450b9100d285/nod e/1t5450b859e4e6b
Vicki, Batts. 2019. Disturbing study reveals connection between brain damage and hepatitis B vaccine [online]. Newstarget. Cited 2019 June 24. From: https://www.newstarge t.com/2019-02-17-disturbing-study-r eveals-connection-between-brain-da $\underline{\text { mage-and-hepatitis-b-vaccine.html }}$

Wang, X., et al. "IL-4 mediates the delayed neurobehavioral impairments induced by neonatal hepatitis $\mathrm{B}$ vaccination that involves the down regulation of the IL4 receptor in the hippocampus", Elsevier, 110. 137-49. 